\title{
Mycobacteria activate $\gamma \delta$ T-cell anti-tumour responses via cytokines from type 1 myeloid dendritic cells: a mechanism of action for cancer immunotherapy
}

\author{
Daniel W. Fowler $\cdot$ John Copier $\cdot$ Natalie Wilson • \\ Angus G. Dalgleish · Mark D. Bodman-Smith
}

Received: 10 August 2011 / Accepted: 23 September 2011 / Published online: 15 October 2011

(C) The Author(s) 2011. This article is published with open access at Springerlink.com

\begin{abstract}
Attenuated and heat-killed mycobacteria display demonstrable activity against cancer in the clinic; however, the induced immune response is poorly characterised and potential biomarkers of response ill-defined. We investigated whether three mycobacterial preparations currently used in the clinic (BCG and heat-killed Mycobacterium vaccae and Mycobacterium obuense) can stimulate anti-tumour effector responses in human $\gamma \delta$ T-cells. $\gamma \delta$ $\mathrm{T}$-cell responses were characterised by measuring cytokine production, expression of granzyme B and cytotoxicity against tumour target cells. Results show that $\gamma \delta$ T-cells are activated by these mycobacterial preparations, as indicated by upregulation of activation marker expression and proliferation. Activated $\gamma \delta$ T-cells display enhanced effector responses, as shown by upregulated granzyme B expression, production of the $\mathrm{T}_{\mathrm{H}} 1$ cytokines IFN $-\gamma$ and TNF- $\alpha$, and enhanced degranulation in response to susceptible and zoledronic acid-treated resistant tumour cells. Moreover, $\gamma \delta$ T-cell activation is induced by IL- 12 , IL- $1 \beta$ and TNF- $\alpha$ from circulating type 1 myeloid dendritic cells (DCs), but not from type 2 myeloid DCs or plasmacytoid DCs. Taken together, we show that BCG, M. vaccae and M. obuense induce $\gamma \delta$ T-cell anti-tumour effector responses indirectly via a specific subset of circulating DCs and suggest a mechanism for the potential immunotherapeutic effects of BCG, $M$. vaccae and $M$. obuense in cancer.
\end{abstract}

Electronic supplementary material The online version of this article (doi:10.1007/s00262-011-1121-4) contains supplementary material, which is available to authorized users.

D. W. Fowler $(\varangle) \cdot$ J. Copier · N. Wilson · A. G. Dalgleish ·

M. D. Bodman-Smith

Department of Clinical Sciences,

St. George's University of London, Cranmer Terrace,

Tooting Broadway, London SW17 0RE, UK

e-mail: dfowler@sgul.ac.uk
Keywords $\quad \gamma \delta$ T-cell $\cdot$ Myeloid dendritic cell . Mycobacteria $\cdot$ Immunotherapy $\cdot$ Cancer

\section{Introduction}

The immune system's intrinsic ability to recognise and destroy tumour cells is an attractive target for therapeutic intervention. Moreover, cancer patients are often immunocompromised due to the immunosuppressive nature of the tumour and collateral affects of certain chemotherapies. Cancer immunotherapy aims to bolster appropriate antitumour immune responses; an approach that has great potential as a stand-alone treatment or combinatorial partner of standard chemotherapy. Indeed, cancer immunotherapy has had many successes, with one of the most prominent milestones to date being the use of Bacillus Calmette Guérin (BCG) to treat bladder cancer [1].

The remarkable success of BCG therapy in bladder cancer highlights the potential for mycobacterial preparations as cancer immunotherapeutic agents or as adjuvants to existing chemotherapies. There has also been considerable interest in a heat-killed preparation of Mycobacterium vaccae for the treatment of cancers of the prostate, lung, kidney and skin [2-5]. In particular, M. vaccae combined with chemotherapy increased survival and improved quality of life in phase III trials for adenocarcinoma of the lung [6, 7]. Recently, attention has turned to heat-killed preparations of $M$. obuense, which are currently undergoing early phase trials in melanoma [8]. Although mycobacterial preparations are currently under clinical investigation, mechanistic studies are limited and biomarkers of response ill-defined, which is hampering their success. In vitro studies are needed to identify candidate immune cells for immunological monitoring during clinical trials. $\gamma \delta$ T-cells have a number of properties 
that highlight them as a potential mechanism by which mycobacterial preparations elicit their anti-cancer effects. In particular, $\gamma \delta$ T-cells play a demonstrable role in protective immunosurveillance against cancer [9-11]; are highly reactive against mycobacterial antigens [12]; and display potent cross-reactivity against tumour cells and mycobacteria [13]. However, the capacity for clinical preparations of BCG, $M$. vaccae and $M$. obuense to elicit effector responses in $\gamma \delta$ $\mathrm{T}$-cells has been largely overlooked and remains poorly characterised.

$\gamma \delta$ T-cells can elicit protective immune responses against cancer and are an essential component of the anti-tumour immune response. In vitro, human $\gamma \delta$ T-cells display potent cytotoxicity against tumour cells from a broad range of epithelial and haematalogic malignancies [14-16]. They also produce interferon (IFN)- $\gamma$ and tumour necrosis factor (TNF)- $\alpha$ in response to mycobacteria and tumour, which potentiate protective cell-mediated immune responses against cancer [17]. Moreover, $\gamma \delta$ T-cell responses to antigenic challenge are rapid and memory-like, thus providing an early defence mechanism that complements the delayed immune response of $\alpha \beta$ T-cells [18]. In contrast to $\alpha \beta$ T-cells, $\gamma \delta$ T-cells recognise phosphoantigens independently of major histocompatibility complex (MHC) class I, which is often down-modulated in a range of cancers, thus reinforcing the value of $\gamma \delta$ T-cells in cancer immunotherapy [19]. $\gamma \delta$ T-cells also express the natural killer activatory receptor NKG2D; this receptor interacts with MHC class I-related stress molecules such as MICA and MICB, which are frequently upregulated on tumours [20].

Our aim was to examine whether BCG and heat-killed $M$. vaccae and $M$. obuense can prime $\gamma \delta$ T-cells for an antitumour effect. Data presented herein suggest that these mycobacterial preparations stimulate anti-tumour responses in $\gamma \delta \mathrm{T}$-cells, as shown by production of $\mathrm{T}_{\mathrm{H}} 1$ cytokines, upregulation of granzyme $\mathrm{B}$ and increased cytotoxicity against tumour cells. Furthermore, data suggest that $\gamma \delta$ T-cell responses are indirectly stimulated by IL-12, IL- $1 \beta$ and TNF- $\alpha$ from circulating type 1 myeloid dendritic cells (mDC1s). Taken together, our study is the first to demonstrate that BCG, $M$. vaccae and $M$. obuense may enhance the effector responses of $\gamma \delta$ T-cells by stimulating mDC1s to produce IL-12, IL- $1 \beta$ and TNF- $\alpha$, which sheds light on the mechanism of action for the anti-cancer effects of these immunotherapies.

\section{Materials and methods}

Mycobacteria

Heat-killed M. vaccae and M. obuense were supplied by Professor John Stanford (University College London).
Mycobacteria were heat-killed by autoclaving at $121^{\circ} \mathrm{C}$ for 15 min in borate-buffered solution. Lyophilised BCG vaccine (Danish strain 1331; Statens Serum Institut) was resuspended in phosphate-buffered saline (PBS; Sigma) and heat-killed as described above. Mycobacteria were added to cell cultures using optimised doses of $1 \times 10^{5}$ culturable particles/ml BCG, $100 \mu \mathrm{g} / \mathrm{ml} \mathrm{M.} \mathrm{vaccae} \mathrm{and} 100 \mu \mathrm{g} / \mathrm{ml}$ M. obuense (supplementary fig. 1).

\section{Cell isolation/depletion}

Peripheral blood mononuclear cells (PBMCs) were isolated from healthy donors by density-adjusted centrifugation using Histopaque $-1,077$ (Sigma). Contaminating red blood cells were lysed with hypotonic ammonium chloride (5 Prime) and platelets removed by centrifugation at $200 \mathrm{~g}$. Specific cell populations were isolated or depleted from PBMCs using magnetic microbeads against $\mathrm{TCR} \gamma \delta, \mathrm{CD} 14, \mathrm{CD} 4, \mathrm{CD} 8$, CD19, CD56 and/or CD1c (Miltenyi Biotec) according to the manufacturer's instructions. Purities for cell isolations were analysed by flow cytometry and were consistently $>95 \%$.

\section{Cell culture}

All cell cultures were performed at $37^{\circ} \mathrm{C}$ with $5 \% \mathrm{CO}_{2}$. $1 \times 10^{6}$ PBMCs in $200 \mu \mathrm{l}$ complete medium RPMI-1640 (Sigma) with $5 \%$ heat-inactivated human A/B serum (Lonza) and $2 \mathrm{mM}$ L-glutamine (Sigma), were cultured in 96-well, flat-bottomed tissue culture plates. For proliferation assays, PBMCs were stained with $400 \mathrm{nM}$ carboxyfluorescein diacetate succinimidyl ester (CFSE; Invitrogen) and $1 \times 10^{6}$ cells in $1 \mathrm{ml}$ of complete medium cultured in 24-well tissue culture plates for 6 days. The percentage of cells with CFSE fluorescence lower than the untreated controls was used as a measure of proliferation. $2-5 \times 10^{4}$ purified $\gamma \delta$ T-cells in $200 \mu \mathrm{l}$ of complete medium were cultured in 96-well, round-bottomed tissue culture plates alone or with $\mathrm{CD}^{2} 6^{+}, \mathrm{CD} 4^{+}, \mathrm{CD}^{+}$or $\mathrm{CD} 1 \mathrm{c}^{+}$cells. For some experiments, $\gamma \delta$ T-cells were cultured overnight with recombinant human IL-12 (Miltenyi Biotec), IL-1 $\beta$ and TNF- $\alpha$ (both Peprotech) at concentrations indicated in figure legends. $1 \times 10^{6} \mathrm{CD}^{+}$cells in $200 \mu \mathrm{l}$ complete medium were cultured in 96-well, flat-bottomed tissue culture plates. For some experiments, supernatants were collected and passed through $0.2-\mu \mathrm{m}$ filters prior to use. For intracellular cytokine staining, $1 \mu \mathrm{g} / \mathrm{ml}$ of Brefeldin A (Sigma) was added for the last $4 \mathrm{~h}$ of culture.

The following positive controls were used: isopentenyl pyrophosphate (IPP; $10 \mu \mathrm{g} / \mathrm{ml}$ ); phorbol myristate acetate (PMA; $25 \mathrm{ng} / \mathrm{ml}$ ); ionomycin (I; $1 \mu \mathrm{g} / \mathrm{ml}$ ); phytohaemagglutinin-leucoagglutinin (PHA-L; $1 \mu \mathrm{g} / \mathrm{ml}$ ); lipopolysaccharide (LPS; E. coli-derived; $1 \mu \mathrm{g} / \mathrm{ml}) ; \mathrm{R} 848(2.5 \mu \mathrm{g} / \mathrm{ml})$ (all from Sigma); and IL-2 (5U/ml; Peprotech). 
The Burkitt's Lymphoma cell line Daudi and lung carcinoma cell line A549 (both ECACC) were cultured in RPMI-1640 or Dulbecco's modified eagle media (DMEM; Sigma), respectively, supplemented with $10 \%$ foetal bovine serum (FBS; Invitrogen) and $2 \mathrm{mM}$ L-glutamine. $2 \times 10^{6}$ A549 cells were added per $75 \mathrm{~cm}^{2}$ tissue culture flask and allowed to adhere for $24 \mathrm{~h}$ prior to overnight culture with $0.1,1$ or $10 \mu \mathrm{M}$ of zoledronic acid (Novartis).

\section{Flow cytometry}

Cells were stained in buffer (PBS with $1 \%$ albumin bovine serum (Sigma) and $0.1 \%$ sodium azide (Sigma) for $30 \mathrm{~min}$ at $4^{\circ} \mathrm{C}$ with the following monoclonal antibodies: CD3FITC, CD3-PERCP, TCR $\gamma \delta$-PE, V $\delta 2$-PE, CD69-FITC, CD69-PE, CD69-APC, HLA-DR-PERCP, CD25-APC, CD4-PE, CD123-PE, CD123-PECy5 and CD14-APC (all from Becton-Dickinson); CD11c-FITC, CD11c-PE and CD1c-PE (all from Miltenyi Biotec); and V $\delta 1$-FITC (Thermo Scientific). Matched isotype control antibodies were used to determine background staining. Cells were then fixed in 4\% paraformaldehyde (BD Cellfix; BectonDickinson) for $20 \mathrm{~min}$ at $4^{\circ} \mathrm{C}$. For intracellular cytokine staining, cells were simultaneously fixed and permeabilised in $4 \%$ paraformaldehyde and $0.1 \%$ saponin (BD Cytofix/ Cytoperm; Becton-Dickinson) for $20 \mathrm{~min}$ at $4^{\circ} \mathrm{C}$ and then resuspended in $0.1 \%$ saponin with IFN- $\gamma$-APC, TNF- $\alpha$ APC, IL-10-APC, IL-12-APC (all from Miltenyi Biotec), IFN- $\gamma$-PECy7 (Becton-Dickinson), IL-1 $\beta$-APC (R and D Systems) or Granzyme B-APC (Caltag-Medsystems) for $10 \mathrm{~min}$ at room temperature. Expression levels were analysed using FACsCalibur or LSRII with CellQuest Pro or FACs DIVA software, respectively (all Becton-Dickinson).

Tritiated ${ }^{3} \mathrm{H}$ incorporation

Tritiated $\left[{ }^{3} \mathrm{H}\right]$-thymidine incorporation was used to assess proliferation of purified $\gamma \delta$ T-cells. Cells were cultured with mycobacteria for 6 days prior to the addition of $2.5 \mu \mathrm{Ci} / \mathrm{ml}$ $\left[{ }^{3} \mathrm{H}\right]$-thymidine (GE Healthcare) for the last $18 \mathrm{~h}$ of culture. Cells were osmotically lysed and DNA collected onto filters (Perkin Elmer). Scintillation fluid (Perkin Elmer) was added prior to measuring beta emission (photon counts per minute) using a liquid scintillation counter (Perkin Elmer).

Cytokine analysis of culture supernatants

$\mathrm{T}_{\mathrm{H}} 1 / \mathrm{T}_{\mathrm{H}} 2$ cytometric bead arrays (CBAs; Becton-Dickinson) were used to measure the concentration of IFN- $\gamma$, TNF- $\alpha$, IL-10, IL-5, IL-4 and IL-2 in cell culture supernatants according to the manufacturer's instructions. Supernatants were also analysed by multi-analyte profiling of inflammation-related analytes by Rules Based Medicine (USA).
Cytotoxicity assays

Mycobacteria-stimulated PBMCs were co-cultured with Daudi or zoledronic acid-treated A549 cells at a pre-optimised effector:target cell ratio of 2:1. Antibodies to CD107bFITC and CD107a-APC or IgG1 $\kappa$-FITC and IgG1 $\kappa$-APC (Becton-Dickinson) were added directly to the wells. Cocultures were incubated for $1 \mathrm{~h}$ prior to addition of $1 \mu \mathrm{g} / \mathrm{ml}$ monensin (Sigma) to neutralise intracellular acidity. After a further $5 \mathrm{~h}$ of culture, $\mathrm{V} \delta 2 \mathrm{~T}$-cell expression of CD107a and $\mathrm{CD} 107 \mathrm{~b}$ was assessed by flow cytometry. Alternatively, cytokine-treated $\gamma \delta$ T-cells were co-cultured overnight with Daudi cells at target:effector cell ratios of 1:10, 1:20 and 1:50 in 96-well, V-bottomed tissue culture plates. Cytotoxicity was assessed using the lactate dehydrogenase assay (Promega) according to the manufacturer's instructions. Percentage cytotoxicity was calculated against maximum target cell release using 9\% Triton X-100 (Promega).

\section{Blocking experiments}

PBMCs were cultured overnight with mycobacteria in the presence of blocking antibodies to IL-12, IL- $1 \beta$ and TNF- $\alpha$ ( $\mathrm{R}$ and D Systems) each at $100 \mu \mathrm{g} / \mathrm{ml}$. Also, culture supernatants from mycobacteria-treated $\mathrm{CD}^{+}$cells were pretreated for $1 \mathrm{~h}$ with blocking antibodies to IL-12, IL-1 $\beta$ and/or TNF- $\alpha$ each at $100 \mu \mathrm{g} / \mathrm{ml}$ prior to culturing with $\gamma \delta$ T-cells. Goat IgG1 isotype antibodies (R and D Systems) were used as controls throughout.

Statistical analyses

Statistical testing was carried out using SigmaStat (SPSS Inc.) analytical software. Statistical differences between conditions were determined using one-way ANOVA (for parametric data with equal variances and normal distributions) or Kruskal-Wallis ANOVA on ranks (for non-parametric data) followed by either Holm-Sidak or Dunn's Tests, respectively. For some experiments, statistical differences between conditions were determined using the student's paired t test. Differences with $P$ values less than 0.05 were deemed significant.

\section{Results}

$\gamma \delta$ T-cells within mycobacteria-treated PBMCs produce granzyme $\mathrm{B}$ and $\mathrm{T}_{\mathrm{H}} 1$ cytokines

To determine the effects of mycobacterial adjuvants on $\gamma \delta$ T-cells, we measured activation, proliferation, granzyme $\mathrm{B}$ expression and cytokine production by $\gamma \delta$ T-cells within BCG-, M. vaccae- and M. obuense-treated PBMCs. 
Preliminary experiments show that live and heat-killed BCG were equipotent at upregulating CD69 on $\gamma \delta$ T-cells (supplementary fig. 1a). Using the pre-optimised concentrations determined in supplementary figs. $1 \mathrm{a}$ and $1 \mathrm{~b}$, heatkilled BCG, M. vaccae and M. obuense upregulated CD69, CD25 and HLA-DR expression on $\gamma \delta$ T-cells (Fig. 1a). Activation was restricted to the $\mathrm{V} \delta 2^{+}$subset, as shown by upregulated CD69 expression in $\mathrm{V} \delta 2^{+}$but not $\mathrm{V} \delta 1^{+}$cells (Fig. 1b). The mycobacteria induced proliferation in $\gamma \delta \mathrm{T}$ cells; however, levels of proliferation against BCG and $M$. obuense were markedly higher than against $M$. vaccae (Fig. 1c). Changes in the percentage of $\gamma \delta$ T-cells within PBMCs after 6 days of mycobacterial stimulation were only minor and not significant (data not shown), suggesting that other cell types are also proliferating. Moreover, the mycobacteria upregulated $\gamma \delta$ T-cell expression of granzyme B (Fig. 1d). Analysis of supernatants from mycobacteria-treated PBMCs indicated detectable levels of IFN- $\gamma$, TNF- $\alpha$ and IL-10, but relatively low levels of IL-5, IL-4 and IL-2 (data not shown). Intracellular cytokine staining revealed that $\gamma \delta$ T-cells produced IFN- $\gamma$ and TNF- $\alpha$, but not IL-10 (Fig. 1e).

Mycobacteria-activated $\mathrm{V} \delta 2^{+}$cells have enhanced cytotoxicity against tumour cells

Upregulation of granzyme B suggests that mycobacteriaactivated $\gamma \delta$ T-cells may have enhanced cytotoxic properties. We investigated the ability of mycobacteria-activated $\gamma \delta$ T-cells to degranulate in the presence of tumour cells. The Burkitt's lymphoma cell line Daudi and the lung cancer cell line A549 were selected as $\gamma \delta$ T-cell susceptible and resistant tumour target cells, respectively. Resting $\mathrm{V} \delta 2^{+}$cells increased CD107a/b expression when exposed to Daudi but not A549 target cells (Fig. 2a). Mycobacteriaactivated $\mathrm{V} \delta 2^{+}$cells had higher levels of Daudi-induced $\mathrm{CD} 107 \mathrm{a} / \mathrm{b}$ expression than untreated $\mathrm{V} \delta 2^{+}$cells (Fig. $2 \mathrm{~b}-$ d). Pre-treating A549 cells with zoledronic acid increased their capacity to induce degranulation in resting $\mathrm{V} \delta 2^{+}$cells (Fig. 2e). Moreover, mycobacteria-activated $\mathrm{V} \delta 2^{+}$cells had increased percentage expression of $\mathrm{CD} 107 \mathrm{a} / \mathrm{b}$ and mean fluorescence intensity (MFI) expression of CD107a in response to A549 cells pre-treated with zoledronic acid (Fig. 2e). Taken together, mycobacterial adjuvants enhance $\gamma \delta$ T-cell degranulation in the presence of susceptible tumours but further treatment was required to expose this effect in tumours that are refractory to $\gamma \delta$ T-cell killing.

$\mathrm{V} \delta 2^{+}$cell responses to mycobacteria are dependent on $\mathrm{CD} 4^{+}$cells

A range of cell types have been implicated in mediating $\gamma \delta$ T-cell activation [21-23]. To determine whether the effect of BCG, M. vaccae and M. obuense on $\gamma \delta$ T-cells is direct or mediated by another cell type, the capacity for these mycobacterial preparations to activate highly purified $\gamma \delta$ T-cells was assessed. Purified $\gamma \delta$ T-cells (mean \pm SD: $98.2 \pm 1.1 \%$ ) were not activated by the mycobacteria, as shown by baseline levels of CD69 expression, cytokine production and proliferation (Fig. $3 \mathrm{a}-\mathrm{c}$ ). To determine the cell type required for activation, PBMCs were sequentially depleted of $\mathrm{CD}^{+} 4^{+}$cells (monocytes), $\mathrm{CD} 19^{+}$cells (B-cells) and $\mathrm{CD} 56^{+}$cells (NK and NKT cells) prior to overnight stimulation and analysis of CD69 expression on $\mathrm{V} \delta 2^{+}$cells. Depletion of $\mathrm{CD} 14^{+}$monocytes augmented mycobacteriainduced $\mathrm{V} \delta 2^{+}$cell expression of CD69 (Fig. 3d) and IFN- $\gamma$ (data not shown), suggesting that in our system monocytes are inhibitory. Furthermore, co-culturing $\gamma \delta$ T-cells with monocytes failed to restore their response to the mycobacteria (data not shown). Subsequent depletion of CD19 ${ }^{+}$ B-cells had no effect, whereas depletion of $\mathrm{CD}^{2} 6^{+} \mathrm{NK}$ and NKT cells reduced mycobacteria-induced CD69 expression on $\mathrm{V} \delta 2^{+}$cells (Fig. 3d). Purified $\gamma \delta$ T-cells were then stimulated with mycobacteria in the presence of either $\mathrm{CD} 56^{+}$ cells or a combination of $\mathrm{CD}^{+}$and $\mathrm{CD} 8^{+}$cells prior to flow cytometric analysis of IFN- $\gamma$ production. In the presence of $\mathrm{CD} 4^{+} / \mathrm{CD}^{+}$cells but not $\mathrm{CD} 56^{+}$cells, the mycobacteria induced IFN $-\gamma$ production by $\mathrm{V} \delta 2^{+}$cells (Fig. 3e). Furthermore, $\mathrm{CD}^{+}$but not $\mathrm{CD} 8^{+}$cells were responsible for restoring $\gamma \delta \mathrm{T}$-cell responses to the mycobacterial preparations (Fig. 3f).

$\mathrm{V} \delta 2^{+}$cells are activated by IL- 12 , IL- $1 \beta$ and TNF- $\alpha$ released from mycobacteria-stimulated $\mathrm{CD} 4^{+}$cells

We assessed whether soluble mediators are responsible for $\gamma \delta$ T-cell activation. Culture supernatants from mycobacteria-stimulated $\mathrm{CD} 4^{+}$cells were added to purified $\gamma \delta$ T-cells, and IFN- $\gamma$ production by the $\mathrm{V} \delta 2^{+}$subset was measured. Results show that culture supernatants from treated $\mathrm{CD} 4^{+}$ cells upregulated IFN- $\gamma$ production by $\mathrm{V} \delta 2^{+}$cells (Fig. 4a). Multi-analyte profiling of culture supernatants from mycobacteria-treated $\mathrm{CD}_{4}^{+}$cells revealed the presence of a number of cytokines (data not shown). Of these, IL-12, IL-1 and TNF have been previously shown to mediate $\gamma \delta$ T-cell activation [24-26]. To determine the role played by these three cytokines, PBMCs were stimulated with mycobacteria in the presence of blocking antibodies to IL-12, IL- $1 \beta$ and TNF- $\alpha$. This resulted in a marked reduction in $\mathrm{V} \delta 2^{+}$cell IFN- $\gamma$ production (Fig. $4 \mathrm{~b}$ ), indicating that these cytokines are key mediators in $\gamma \delta$ T-cell activation. To confirm this observation, isolated $\gamma \delta$ T-cells were stimulated with conditioned media from mycobacteria-treated $\mathrm{CD} 4^{+}$cells in the presence of blocking antibodies to IL-12, IL- $1 \beta$ and TNF- $\alpha$. Results show that blocking these cytokines reduced $\mathrm{V} \delta 2^{+}$ cell IFN- $\gamma$ production (Fig. $4 \mathrm{c}, \mathrm{d}$ ). Analysis of these block- 
a
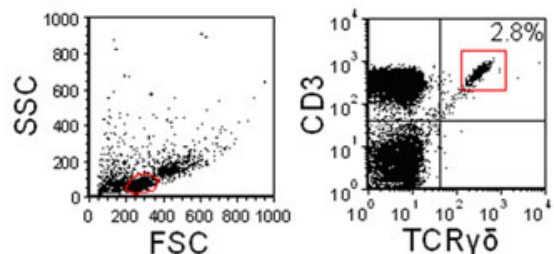

FSC

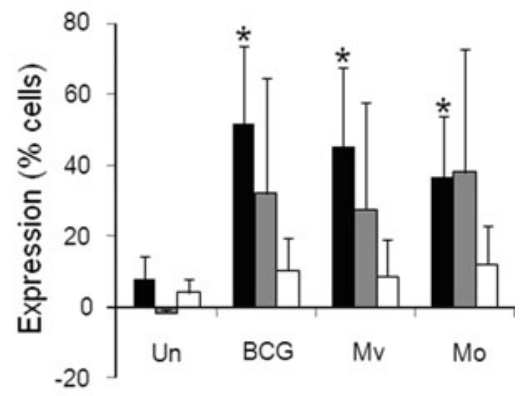

b

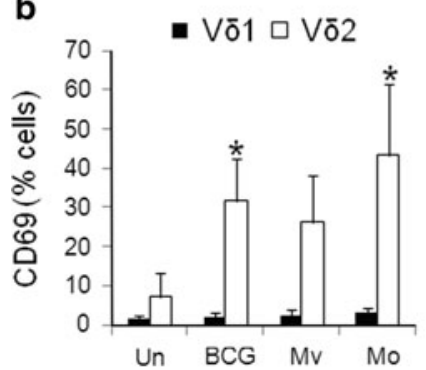

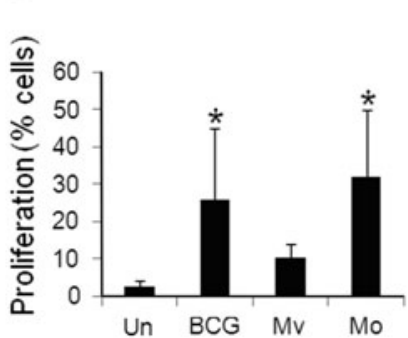

d

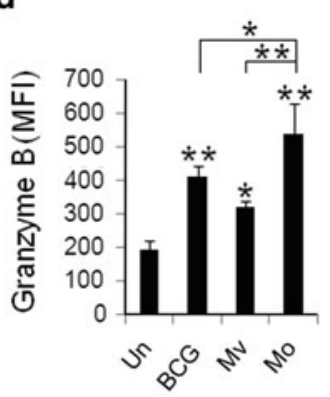

e

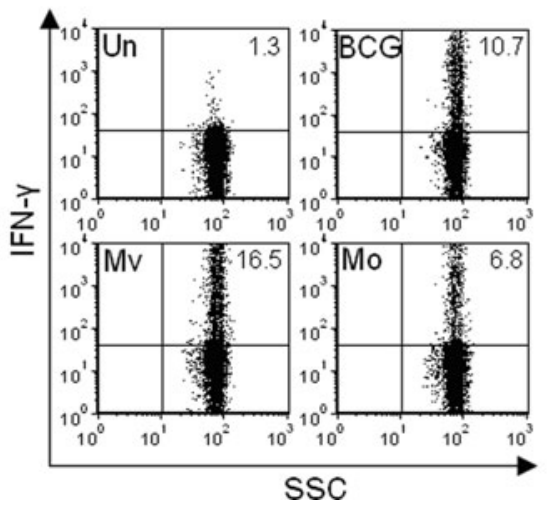

Fig. $1 \gamma \delta$ T-cells within BCG-, M. vaccae- and M. obuense-treated PBMCs produce granzyme $\mathrm{B}$ and $\mathrm{T}_{\mathrm{H}} 1$ cytokines. $\mathrm{PBMCs}$ were cultured with heat-killed $\mathrm{BCG}, M$. vaccae $(\mathrm{Mv})$ and $M$. obuense $(\mathrm{Mo})$ and responses measured within gated $\gamma \delta$ T-cells. Untreated (un) cells were used as a negative control. a Gating strategy used to identify $\gamma \delta$ T-cells within PBMCs. Lymphocytes were gated according to size (forward scatter; FSC) and granularity (side scatter; SSC). Within lymphocytes, $\gamma \delta$ T-cells were gated as $\mathrm{CD}^{+} \mathrm{TCR} \gamma \delta^{+}$. Mean percentages of $\gamma \delta \mathrm{T}$-cells expressing CD69 (at $24 \mathrm{~h} ; n=5$ ), CD25 and HLA-DR (both at $48 \mathrm{~h}$; $n=3$ ) are shown. b Mean percentages of $\mathrm{V} \delta 1^{+}$and $\mathrm{V} \delta 2^{+}$cells express-

ing antibodies either individually or in various combinations revealed a combined effect of all three cytokines (Fig. 4d).

To confirm the key role of these cytokines, we measured $\gamma \delta$ T-cell IFN- $\gamma$ production, granzyme $\mathrm{B}$ expression and cytotoxicity in response to recombinant IL-12, IL-1 $\beta$ and TNF- $\alpha . \gamma \delta$ T-cells cultured with all three cytokines resulted in the greatest IFN- $\gamma$ response in the $\mathrm{V} \delta 2^{+}$subset (Fig. 5a). In accordance with data shown in Fig. 1b, these cytokines

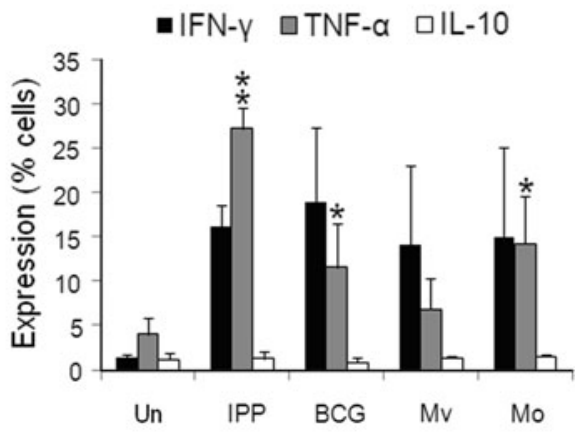

ing CD69 (at $24 \mathrm{~h} ; n=3$ ). $\mathrm{c} \mathrm{CFSE}^{+}$PBMCs were cultured for 6 days with mycobacteria and proliferation measured within the $\gamma \delta$ T-cell compartment. Mean percentages of $\gamma \delta$ T-cells proliferating are shown $(n=6)$. d Mean fluorescent intensities (MFI) of granzyme B expression within $\gamma \delta$ T-cells (at $24 \mathrm{~h} ; n=3$ ). e Percentages of $\gamma \delta \mathrm{T}$-cells expressing IFN- $\gamma$, TNF- $\alpha$ and IL- 10 were measured after $24 \mathrm{~h}$ of stimulation. Representative flow cytometric dot plots from one donor and mean values for $n=3$ are shown. Error bars represent SD. * and ** indicates $P$ values of $<0.05$ and $<0.001$, respectively, for statistical comparisons between treated and untreated cells

did not induce IFN- $\gamma$ production in $\mathrm{V} \delta 2^{-} \gamma \delta$ T-cells (Fig. 5a). IL-12, IL-1 $\beta$ and TNF- $\alpha$ upregulated intracellular expression of granzyme B (Fig. 5b), yet did not induce degranulation, as shown by baseline levels of CD107a expression (data not shown). $\gamma \delta$ T-cells activated with these cytokines showed a marked increase in cytotoxicity against Daudi target cells (Fig. 5c). Together, these data demonstrate that IL-12, IL- $1 \beta$ and TNF- $\alpha$ can induce effector responses in $\gamma \delta$ T-cells. 
a

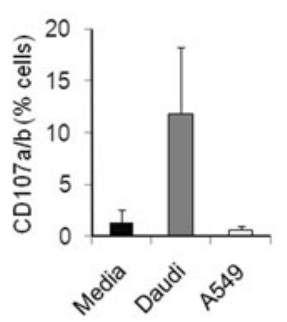

C

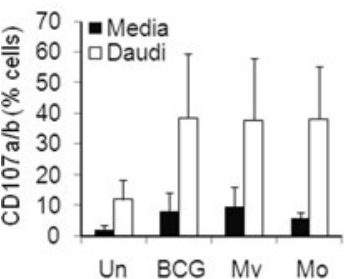

d

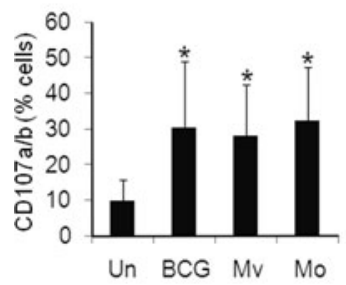

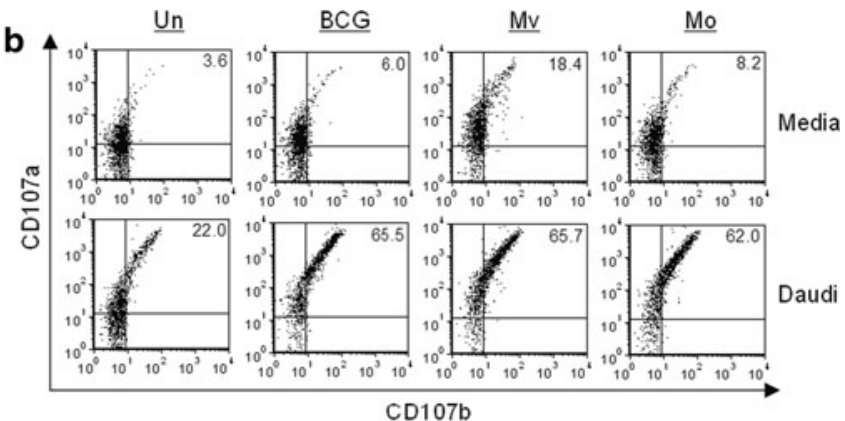

e
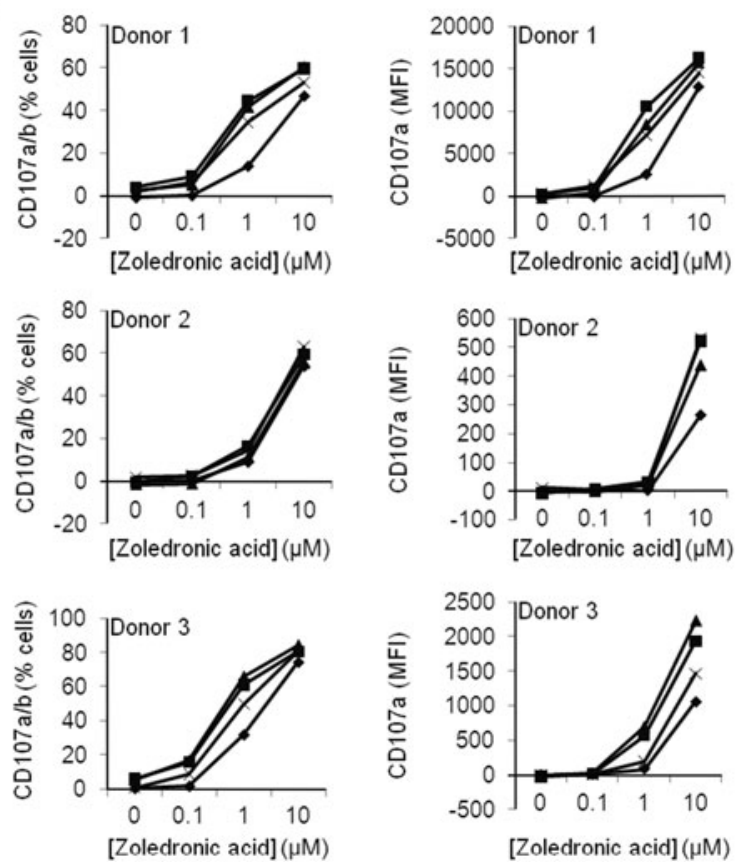

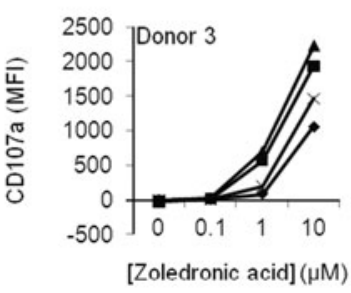

$\rightarrow \mathrm{Un} \rightarrow \mathrm{BCG}+\mathrm{Mv} \rightarrow \mathrm{Mo}$

Fig. 2 BCG, M. vaccae and M. obuense enhance $\gamma \delta$ T-cell cytotoxicity. PBMCs were cultured overnight with heat-killed BCG, M. vaccae (Mv) and M. obuense (Mo). Untreated (un) cells were used as a negative control. PBMCs were then co-cultured for $6 \mathrm{~h}$ with Daudi or A549 cells at an effector:target cell ratio of $2: 1$ and CD107a/b expression measured within gated $\mathrm{V} \delta 2^{+}$cells. a Mean percentage of $\mathrm{V} \delta 2^{+}$cells expressing CD107a/b in the absence (media) or presence of Daudi or A549 target cells $(n \geq 5)$. b Representative flow cytometric dot plots from one donor showing $\mathrm{CD} 107 \mathrm{a} / \mathrm{b}$ expression on gated $\mathrm{V} \delta 2^{+}$cells. c Mean percentage of $\mathrm{V} \delta 2^{+}$cells expressing CD107a/b in the absence (Media) or presence of Daudi target cells $(n=5)$. d Media test scores

\section{IL-12, IL- $1 \beta$ and TNF- $\alpha$ are produced by $\mathrm{CD} 4^{+}$type 1 myeloid DCs}

We have determined the importance of $\mathrm{CD}^{+}$cells and their cytokines in mycobacteria-induced stimulation of $\gamma \delta$ T-cells. However, CD4 is predominantly expressed on $\alpha \beta$ T-cells, which typically do not produce IL-12 or IL- $1 \beta$. These cytokines are mostly associated with antigen presenting cells (APCs) such as monocytes and DCs, which express low levels of CD4. Therefore, we assessed whether APCs are were subtracted from Daudi test scores. Mean values are shown for $n=5$. Error bars represent SD and $*$ indicates a $P$ value of $<0.05$ for statistical comparisons between untreated and treated conditions. For statistical testing, data were standardised by subtracting the untreated scores from test scores. e Percentage of $\mathrm{V} \delta 2^{+}$cells expressing $\mathrm{CD} 107 \mathrm{a} / \mathrm{b}$ and mean fluorescent intensity (MFI) expression of $\mathrm{CD} 107 \mathrm{a}$ on $\mathrm{V} \delta 2^{+}$cells in the presence of zoledronic acid-treated A549 cells. Background levels of degranulation were subtracted from A549induced degranulation. Individual experiments for three donors are shown

present in the $\mathrm{CD} 4^{+}$cell population and measured intracellular expressions of IL-12, IL- $1 \beta$ and TNF- $\alpha$. Monocytes were depleted from the PBMC preparations prior to $\mathrm{CD}^{+}$cell isolation and therefore were not present in the $\mathrm{CD} 4^{+}$cell population. Flow cytometric analysis of CD4, CD3, CD11c, CD123 and CD14 revealed three populations of cells: T-cells $\left(\mathrm{CD} 4^{\text {high }} \mathrm{CD}^{+}\right)$, myeloid DCs (mDCs; $\mathrm{CD} 4^{\text {low }} \mathrm{CD} 3^{-} \mathrm{CD} 11$ $\mathrm{c}^{+} \mathrm{CD} 123^{- \text {low }} \mathrm{CD} 14^{-}$) and plasmacytoid DCs (pDCs; $\mathrm{CD} 4{ }^{\text {low }} \mathrm{CD} 3^{-} \mathrm{CD} 11 \mathrm{c}^{-} \mathrm{CD} 123^{\text {high }} \mathrm{CD} 14^{-}$) (Fig. 6a). Intracellular cytokine staining of mycobacteria-treated $\mathrm{CD}^{+}$cells 

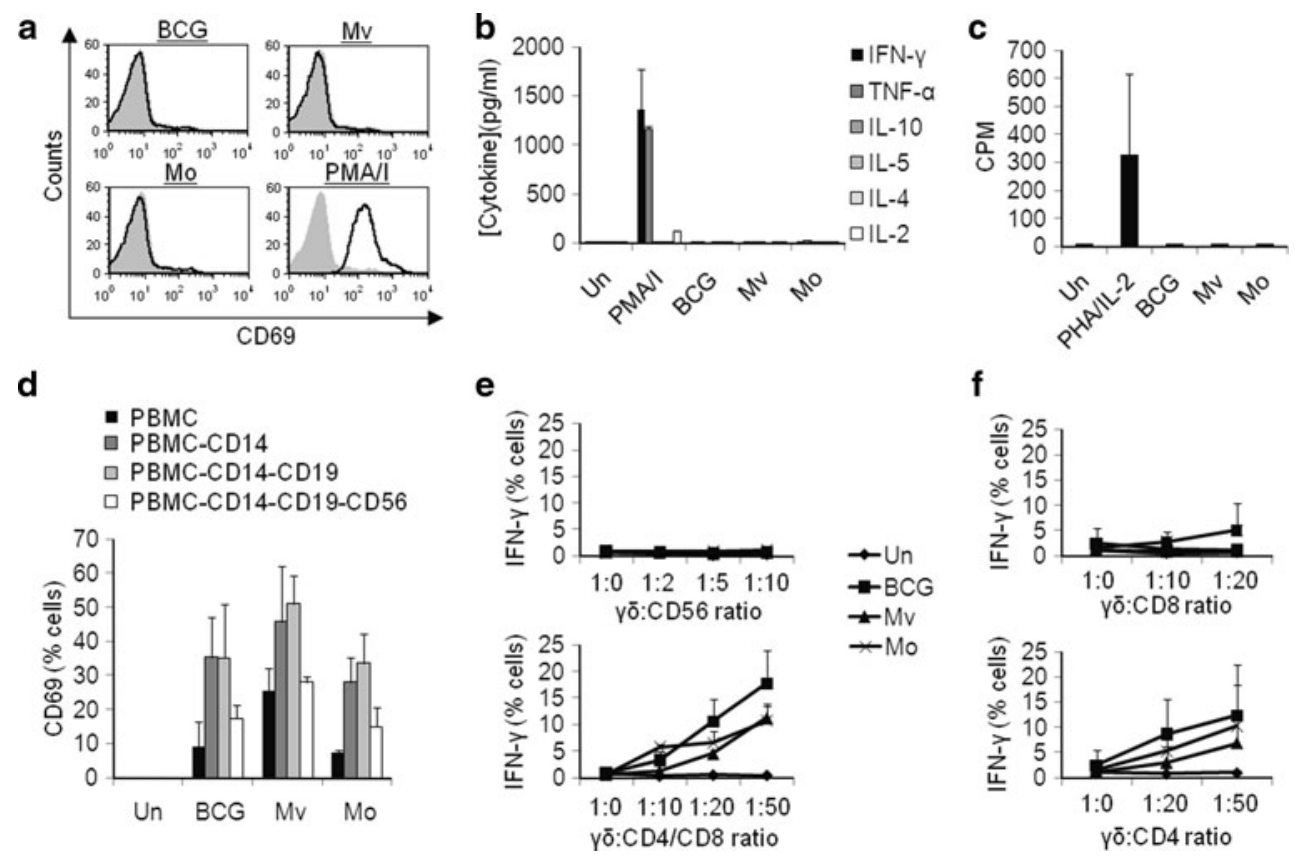

Fig. 3 BCG-, $M$. vaccae- and $M$. obuense-induced activation of $\gamma \delta$ Tcells is dependent on $\mathrm{CD}^{+}$cells. a $\gamma \delta$ T-cells were cultured overnight with PMA/I, heat-killed BCG, M. vaccae (Mv) and M. obuense (Mo) and CD69 expression measured. Representative flow cytometric histogram plots from one of two donors are shown. Expression for untreated cells is shown in grey fill. b Culture supernatants from $\gamma \delta$ T-cells were screened for their cytokine content using cytometric bead arrays. Mean values for $n=3$ are shown. $\mathbf{c} \gamma \delta$ T-cells were cultured with PHA/IL-2, $\mathrm{BCG}, \mathrm{Mv}$ and Mo for 6 days and ${ }^{3} \mathrm{H}$ incorporation measured for the last $16 \mathrm{~h}$ of culture. Mean counts per minute (CPM) are shown for $n=2$. d PBMCs were sequentially depleted of $\mathrm{CD} 14^{+}, \mathrm{CD} 19^{+}$and
$\mathrm{CD}^{+} 6^{+}$cells and stimulated overnight with BCG, Mv and Mo prior to measuring CD69 expression on gated $\mathrm{V} \delta 2^{+}$cells. Data were standardised by subtracting untreated scores from test scores. Mean values for $n=3$ are shown. e $\gamma \delta$ T-cells were co-cultured overnight with CD56 ${ }^{+}$ cells (top graph) or a combination of $\mathrm{CD}^{+}$and $\mathrm{CD}^{+}$cells (bottom graph) in the presence of mycobacteria prior to measuring IFN- $\gamma$ expression on gated $\mathrm{V} \delta 2^{+}$cells. Mean values for $n \geq 2$ are shown. $\mathbf{f} \gamma \delta$ T-cells were co-cultured overnight with either $\mathrm{CD} 8^{+}$(top graph) or $\mathrm{CD}^{+}$(bottom graph) in the presence of mycobacteria prior to measuring IFN- $\gamma$ expression on gated $\mathrm{V} \delta 2^{+}$cells. Mean values for $n=3$ are shown. Error bars represent SD revealed that IL-12, IL-1 $\beta$ and TNF- $\alpha$ were expressed predominantly in mDCs (Fig. 6b).

Two types of $\mathrm{mDC}$ have been defined based on expression of $\mathrm{CD} 123$ : type $1\left(\mathrm{CD} 123^{\text {low }}\right.$ mDC1) and type 2 (CD123- ${ }^{-} \mathrm{mDC} 2$ ) [27]. Analysis of CD123 expression revealed that $\mathrm{CD} 123^{+}$but not $\mathrm{CD} 123^{-} \mathrm{mDCs}$ produced IL-12, IL-1 $\beta$ and TNF- $\alpha$ in response to the mycobacteria, suggesting that $\mathrm{mDC} 1 \mathrm{~s}$ and not $\mathrm{mDC} 2 \mathrm{~s}$ are involved in the $\gamma \delta$ T-cell response to these mycobacterial preparations (data not shown). Accordingly, the majority of the mDC population expressed CD1c, a specific marker for mDC1s (Fig. 6c). To confirm the role of $\mathrm{mDC} 1 \mathrm{~s}$ in the $\gamma \delta$ T-cell response to mycobacteria, we depleted $\mathrm{CD} 1 \mathrm{c}^{+}$cells from the $\mathrm{CD} 4^{+}$cell population and assessed the effects on $\gamma \delta$ T-cell activation. Results show that when $\mathrm{CD} 1 \mathrm{c}^{+}$cells were depleted from $\gamma \delta \mathrm{T}$-cell and $\mathrm{CD} 4^{+}$cell co-cultures, IFN- $\gamma$ production by $\mathrm{V} \delta 2^{+}$cells in response to mycobacteria was lost (Fig. 6d). Taken together, data suggest that $\mathrm{mDC} 1 \mathrm{~s}$ are activated by mycobacteria to produce cytokines that activate $\gamma \delta$ T-cell responses.

\section{Discussion}

As part of our ongoing studies into the mechanisms of action for BCG, $M$. vaccae and $M$. obuense cancer immunotherapy, we investigated the potential role of $\gamma \delta$ T-cells. Our data suggest that BCG, M. vaccae and M. obuense activate an anti-tumour programme in peripheral blood $\mathrm{V} \delta 2^{+}$ $\gamma \delta$ T-cells that is characterised by $\mathrm{T}_{\mathrm{H}} 1$ cytokine production and enhanced cytotoxic responses against tumour. Moreover, our data suggest that these responses are indirectly mediated by IL-12, IL- $1 \beta$ and TNF- $\alpha$ from circulating $\mathrm{mDC} 1 \mathrm{~s}$.

$\gamma \delta$ T-cells are highly responsive to mycobacteria; however, studies have primarily focussed on the stimulatory capacity of live mycobacterial infections and lysate preparations. We focussed on live attenuated BCG and heatkilled $M$. vaccae and M. obuense, which are preparations of mycobacteria that are currently used as cancer immunotherapies in the clinic. Little is known about whether these preparations can stimulate anti-tumour effector responses in $\gamma \delta$ T-cells nor the mechanisms involved. We show here that 
a

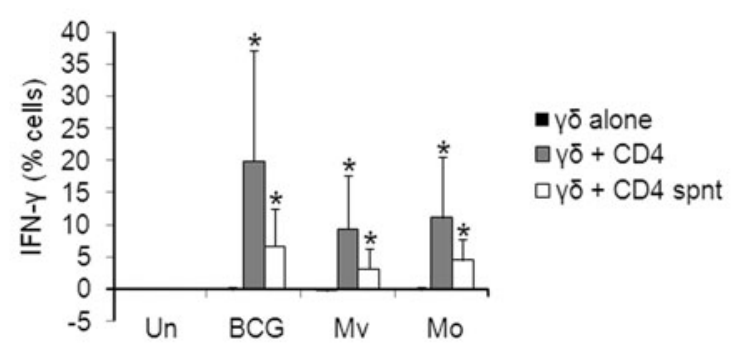

c

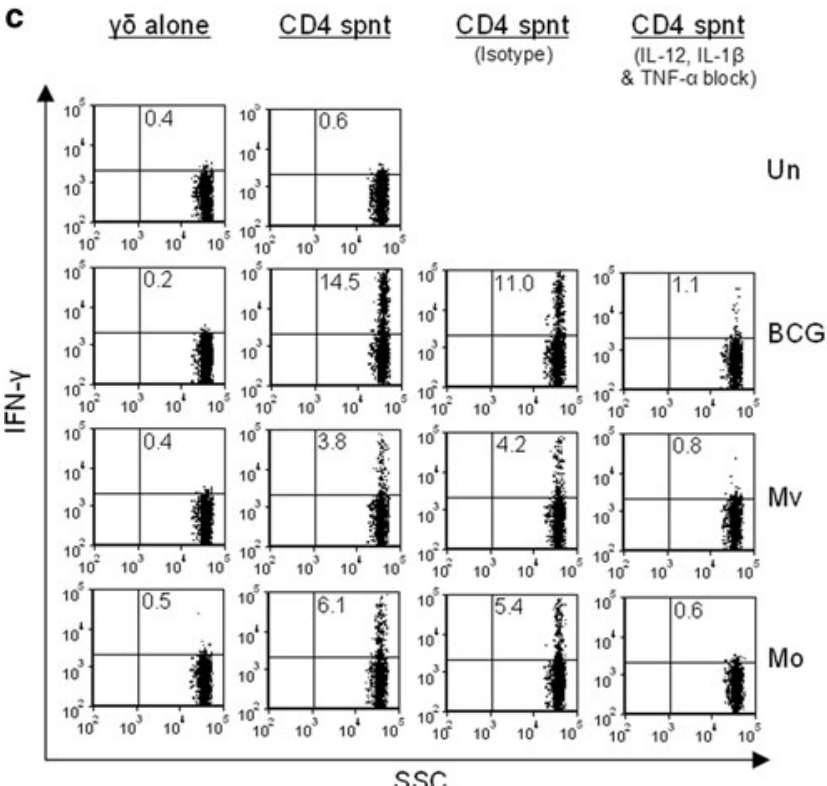

b

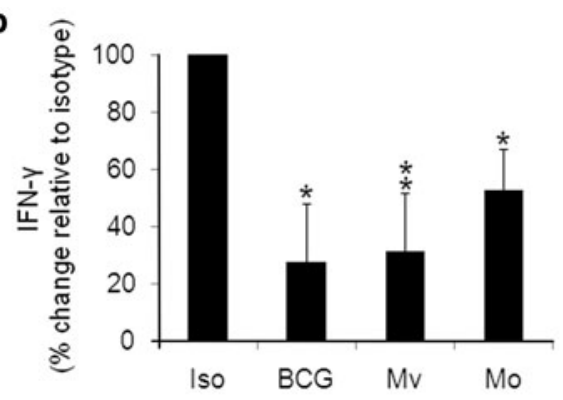

d

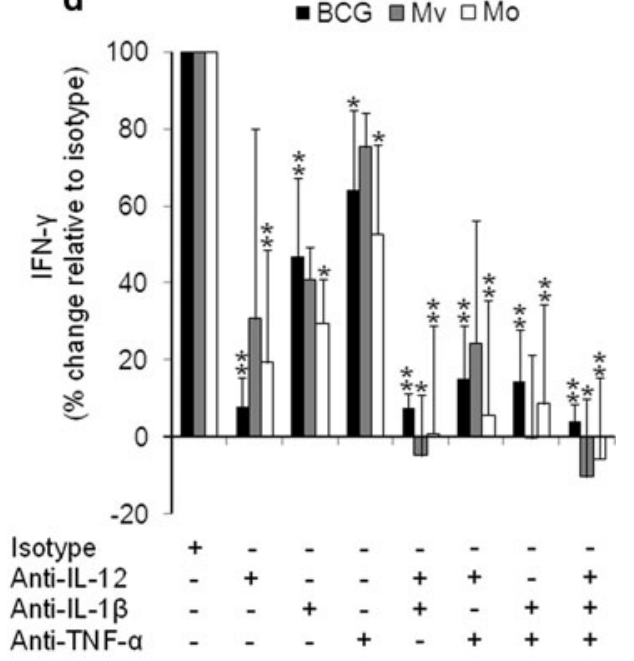

Fig. 4 IL-12, IL- $1 \beta$ and TNF- $\alpha$ from BCG-, M. vaccae- and M. obuense-treated $\mathrm{CD}^{+}$cells activate $\mathrm{V} \delta 2^{+}$cells. a CD4 ${ }^{+}$cells were cultured overnight with heat-killed BCG, M. vaccae (Mv) and $M$. obuense (Mo). $\gamma \delta$ T-cells were then cultured overnight in culture supernatant (spnt) from treated $\mathrm{CD}^{+}$cells prior to measuring IFN- $\gamma$ expression on gated $\mathrm{V} \delta 2^{+}$cells. IFN- $\gamma$ expression was also measured on $\gamma \delta$ T-cells that had been cultured directly with mycobacteria in the presence or absence of $\mathrm{CD}^{+}$cells. Data were standardised by subtracting untreated scores from test scores. b PBMCs were cultured overnight with mycobacteria in the presence of blocking antibodies to IL-12, IL- $1 \beta$ and TNF- $\alpha$ each at $100 \mu \mathrm{g} / \mathrm{ml} .300 \mu \mathrm{g} / \mathrm{ml}$ of isotype

BCG-, $M$. vaccae- and M. obuense-activated PBMCs contain $\gamma \delta$ T-cells that produce the $\mathrm{T}_{\mathrm{H}} 1$ cytokines IFN- $\gamma$ and TNF- $\alpha$, both of which play a demonstrable role in antitumour immunity. Documented effects of these cytokines include the following: MHC class I upregulation on tumour cells, which enhances recognition by cytotoxic $\alpha \beta$ T-cells [28, 29]; cell cycle blockade and pro-apoptotic signalling, which hampers tumour cell growth [30, 31]; and $\mathrm{T}_{\mathrm{H}} 1$ differentiation, which is critical for generating protective immune responses against cancer [32, 33]. Evidence suggests that tumours can evade immune responses by upregulating $\mathrm{T}_{\mathrm{H}} 2$ and downmodulating $\mathrm{T}_{\mathrm{H}} 1$ immune responses; indeed, a $\mathrm{T}_{\mathrm{H}} 2$ bias correlates with disease progression in control antibodies were used as a control. IFN- $\gamma$ expression on gated $\mathrm{V} \delta 2^{+}$cells was then measured. $\mathbf{c} \gamma \delta$ T-cells were cultured overnight with spnts from mycobacteria-treated $\mathrm{CD} 4^{+}$cells in the presence of blocking antibodies to IL-12, IL- $1 \beta$ and TNF- $\alpha$ each at $100 \mu \mathrm{g} / \mathrm{ml}$ prior to measuring IFN- $\gamma$ expression on gated $\mathrm{V} \delta 2^{+}$cells. Representative flow cytometric dot plots are shown. $\mathbf{d}$ Mean percentage of $\mathrm{V} \delta 2^{+}$cells expressing IFN $-\gamma$ relative to isotype control for experiments conducted in c. Data points are mean values $(n=7$ for $\mathbf{a} ; n=3$ for $\mathrm{Mv}$ and Mo in $\mathbf{b} ; n=2$ for BCG in $\mathbf{b}$; and $n=3$ for $\mathbf{d}$ ) where error bars represent SD and $*$ and $* *$ indicate $P$ values of $<0.05$ and $<0.001$, respectively, for statistical comparisons between treated and untreated cells

certain cancers [34]. Therefore, $\gamma \delta$ T-cell production of IFN- $\gamma$ and TNF- $\alpha$ in response to BCG, M. vaccae and $M$. obuense immunotherapy could counteract this tumour escape mechanism and restore the $\mathrm{T}_{\mathrm{H}} 1$ immune responses required to promote anti-cancer immunity.

We also investigated the effects of these mycobacterial preparations on $\gamma \delta$ T-cell cytotoxicity against tumour cells. Studies have shown that $\mathrm{V} \delta 2^{+} \gamma \delta$ T-cells are cytotoxic towards tumour cells from a broad range of haematologic and epithelial cancers [14]. Cytotoxicity is primarily dependent on TCR recognition of phosphoantigens and granzyme/perforin-dependent induction of apoptosis [35]. Also, BCG-specific $\gamma \delta$ T-cell lines are cytotoxic towards 


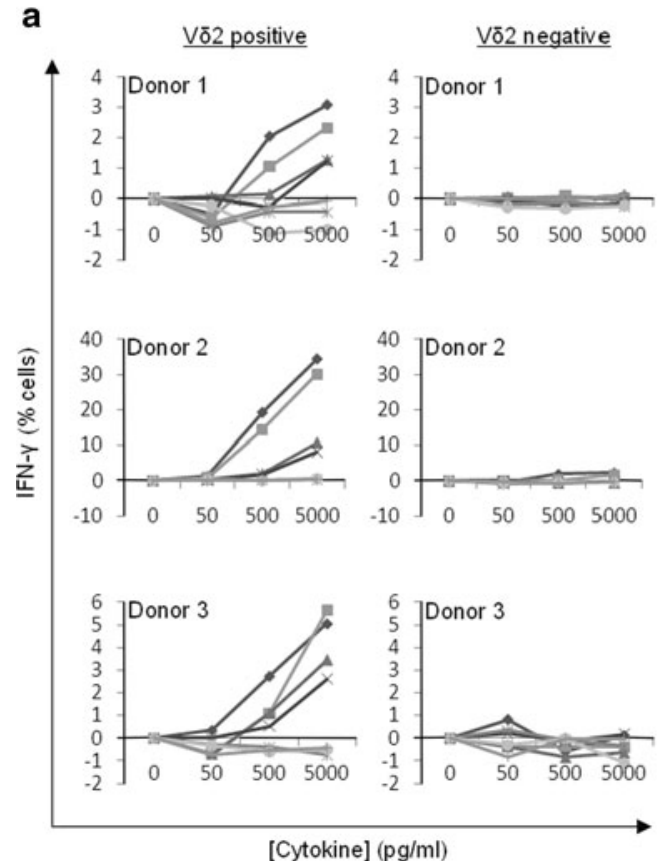

Fig. 5 IL-12, IL- $1 \beta$ and TNF- $\alpha$ induce $\gamma \delta$ T-cell IFN- $\gamma$ production and cytotoxicity. a $\gamma \delta$ T-cells were cultured overnight with different concentrations and combinations of IL-12, IL- $1 \beta$ and TNF- $\alpha$ prior to measuring IFN- $\gamma$ expression on gated $\mathrm{V} \delta 2^{+}$and $\mathrm{V} \delta 2^{-}$cells. Individual experiments from three donors are shown. b MFIs for granzyme B expression on gated $\gamma \delta$ T-cells after overnight culture with $10 \mathrm{ng} / \mathrm{ml}$ each of IL-12, IL-1 $\beta$ and TNF- $\alpha$. Left: Representative flow cytometric histogram plots from one donor. Black fill is the isotype control antibody. Numbers are MFIs within the marker shown. Right: MFI values

tumour cells, suggesting that $\gamma \delta$ T-cells are cross-reactive [13]. However, the ability of heat-killed mycobacteria to enhance $\gamma \delta$ T-cell cytotoxicity has not yet been tested. For the purposes of this study, we used the Burkitt's lymphoma cell line Daudi as a model tumour target as this cell line is routinely used for investigating $\gamma \delta \mathrm{T}$-cell responses against tumour. We found that mycobacteria-stimulated PBMCs contained $\gamma \delta$ T-cells with enhanced cytotoxicity against Daudi cells, as shown by increased degranulation. This effect could be explained by upregulation of cytolytic effector molecules; indeed, we found that mycobacteria upregulated $\gamma \delta$ T-cell expression of granzyme $\mathrm{B}$, which plays a critical role in $\gamma \delta$ T-cell cytotoxicity [36]. Taken together, our data suggest that heat-killed BCG, M. vaccae and M. obuense enhance the cytotoxic activity of $\gamma \delta$ T-cells in PBMCs, which may contribute to the anti-tumour properties of these cancer immunotherapies.

Tumour cell lines that are refractory to $\gamma \delta$ T-cell killing have been reported; indeed, we found that the A549 tumour cell line failed to induce $\gamma \delta$ T-cell degranulation. However, pre-treating A549s with the aminobisphosphonate (ABP) zoledronic acid increased their capacity to induce $\gamma \delta$ T-cell degranulation, which confirms previous studies showing that ABPs upregulate phosphoantigen expression in
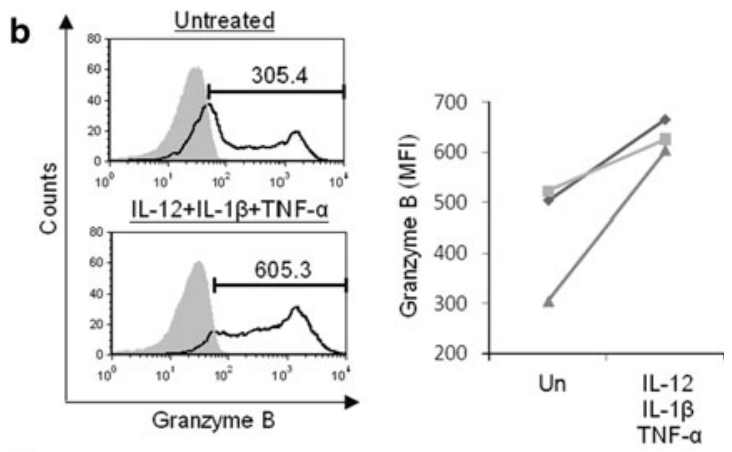

c

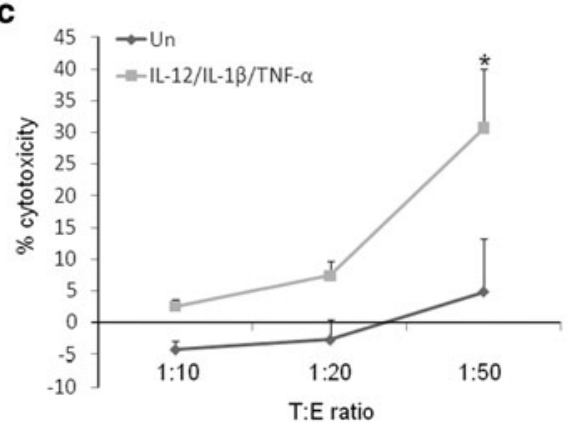

for $n=3$. c Cytokine-activated $\gamma \delta$ T-cells were co-cultured overnight with Daudi cells at the target $(\mathrm{T})$ to effector $(\mathrm{E})$ cell ratios shown. Cytotoxicity was assessed by measuring lactate dehydrogenase release into the culture supernatants. Mean values for $n=3$ (T:E 1:50) and $n=2$ (T:E 1:10 and 1:20) are shown. Untreated (un) cells were used as a negative control throughout. Error bars represent SD deviations and * indicates a $P$ value of $<0.05$ for paired $t$ tests between treatments at the $\mathrm{T}: \mathrm{E}$ ratio of $1: 50$

tumours, thus enhancing recognition by $\mathrm{V} \delta 2^{+} \gamma \delta$ T-cells [37]. We show that PBMCs exposed to heat-killed mycobacteria contain $\gamma \delta$ T-cells with enhanced cytotoxic activity against zoledronic acid-treated A549s. This suggests that systemic priming of $\gamma \delta$ T-cells with mycobacteria could be combined with local treatment of tumours with ABPs, which would serve to simultaneously increase the visibility of the tumour whilst augmenting the cytotoxic responses of circulating effector cells. The anti-cancer effects of ABPs are currently under investigation in lymphoma, myeloma, prostate cancer and breast cancer [38-40]; however, ABPs are currently administered via intravenous infusions, which poses a number of problems. Firstly, ABPs are rapidly absorbed by the mineral surfaces of bone, thus necessitating high-dose regimens that are often associated with a range of complications including pyrexia, nephrotoxicity and electrolyte abnormalities [41]. Intratumoural administration of ABPs combined with systemic mycobacterial priming may be a more effective treatment regimen that reduces these complications. Secondly, ABPs upregulate phosphoantigens in peripheral blood monocytes, which may render them susceptible to $\gamma \delta$ T-cell attack and exhaust $\gamma \delta$ T-cell cytotoxic function before they reach the tumour [42]. Similar to ABPs, the chemotherapies etoposide, cisplatin and 


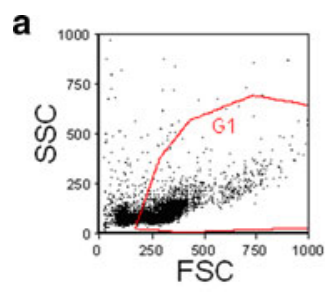

b
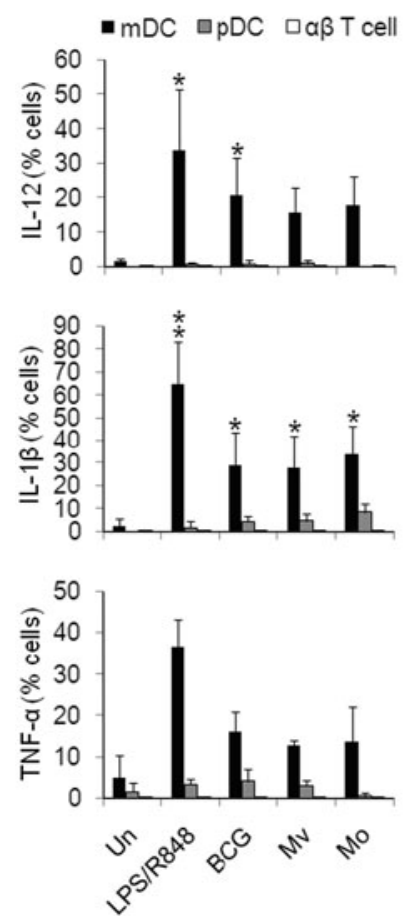

Fig. 6 IL-12, IL- $1 \beta$ and TNF- $\alpha$ are produced by type 1 myeloid DCs. a Flow cytometry was used to measure the expression of CD4, CD3, $\mathrm{CD} 11 \mathrm{c}, \mathrm{CD} 123$ and $\mathrm{CD} 14$ on purified $\mathrm{CD} 4^{+}$cells. From left to right: Debris was excluded according to size and granularity using gate (G) 1. Within the G1 population, CD3 and CD4 expression identified $\mathrm{CD}^{+} \alpha \beta$ T-cells $\left(\mathrm{CD}^{+}{ }^{+} \mathrm{CD} 4^{\text {high }}\right)$ and non-T-cells (CD3 $\left.{ }^{-} \mathrm{CD} 4^{\text {low }} ; \mathrm{G} 2\right)$. Within the $\mathrm{G} 1+\mathrm{G} 2$ non-T-cell population, $\mathrm{CD} 11 \mathrm{c}$ and $\mathrm{CD} 123$ expression identified myeloid DC (mDC) and plasmacytoid DC (pDC) populations, both of which did not express CD14. Representative flow cytometric dot plots from one of two donors are shown. $\mathbf{b ~ C D} 4^{+}$cells were cultured overnight with LPS/R848, heat-killed BCG, $M$. vaccae (Mv) and M. obuense (Mo). Untreated (un) cells were used as a negative

doxorubicin have also been shown to increase the susceptibility of tumour cell lines to $\gamma \delta$ T-cell killing [37]. This suggests there may also be potential in combining certain chemotherapies with $\mathrm{BCG}, M$. vaccae and $M$. obuense immunotherapy; indeed, a survival benefit was reported in lung cancer patients receiving $M$. vaccae in combination with platinum-based chemotherapy $[6,7]$.

In comparing the three different bacterial preparations, only minor differences were observed between them in terms of their activity towards $\gamma \delta$ T-cells. Although this suggests that these different preparations each have the potential to elicit comparable anti-tumour responses in $\gamma \delta$
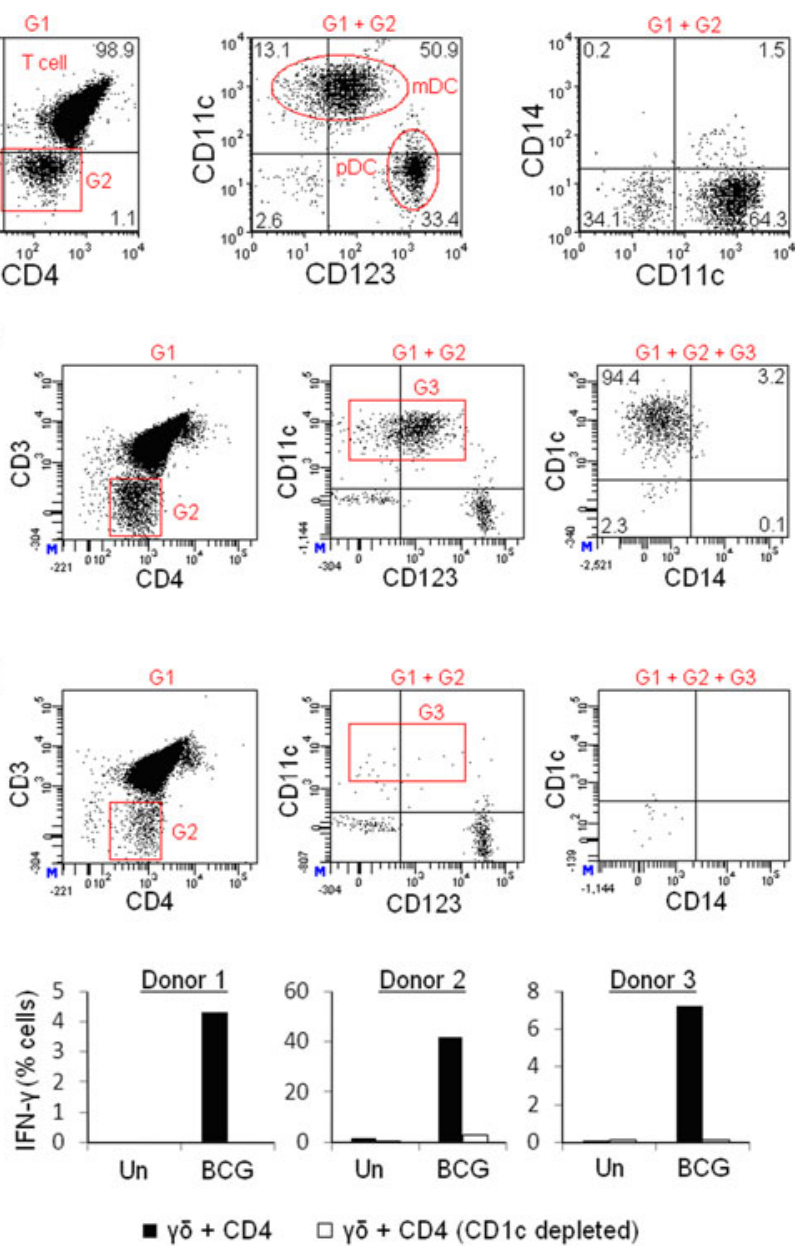

control. IL-12, IL- $1 \beta$ and TNF- $\alpha$ expression was measured on gated T-cells $\left(\mathrm{CD}^{+}\right), \quad \mathrm{mDCs} \quad\left(\mathrm{CD}^{-} \mathrm{CD} 11 \mathrm{c}^{+}\right)$and $\mathrm{pDCs}$ $\left(\mathrm{CD} 3^{-} \mathrm{CD} 11 \mathrm{c}^{-} \mathrm{CD} 123^{\text {high }}\right.$ ). Mean values for $n=3$ are shown (except TNF- $\alpha$, where $n=2$ ). Error bars represent SD. * and $* *$ indicate $P$ values of $<0.05$ and $<0.001$, respectively, for statistical comparisons between treated and untreated conditions. $\mathbf{c}$ CD1c expression was analysed on gated mDCs as shown. d Top panels: CD1c cells were depleted from the $\mathrm{CD}^{+}$cell population. Representative data from one of three donors are shown. Bottom panels: $\gamma \delta$ T-cells were co-cultured overnight with $\mathrm{CD} 4^{+}$cells or $\mathrm{CD} 1 \mathrm{c}$-depleted $\mathrm{CD} 4^{+}$cells in the absence or presence of BCG. Percentage of $\mathrm{V} \delta 2^{+}$cells expressing IFN- $\gamma$ was measured

T-cells, the potential for differential effects on other immune cells remains to be seen. Moreover, the receptors through which they stimulate $\mathrm{mDC} 1 \mathrm{~s}$ may differ, which may have bearing on potential combinatorial partners. Further investigations comparing the induced immune responses of these three bacterial preparations are therefore required and are currently underway.

Although $\gamma \delta$ T-cell responses to BCG have been previously documented, they have been dependent on viable infection of APCs. For example, Martino et al. [23] reported that DCs pre-treated with live, but not heat-killed, BCG activate $\gamma \delta$ T-cells. We found that heat-killed 
mycobacteria can elicit marked $\gamma \delta$ T-cell responses, suggesting there are alternate mechanisms of activation that have yet to be reported. Such mechanisms may be more relevant to cancer immunotherapy since the bulk of reconstituted lyophilised BCG vaccines consist of non-viable bacilli. Furthermore, BCG is slow growing, thus the effects described during live BCG infections are likely to be outweighed by those elicited by non-viable BCG. Current hypotheses suggest that bacterially infected APCs upregulate expression of $\gamma \delta$ T-cell-specific phosphoantigens. In support of this, soluble phosphoantigen-specific $\gamma \delta$ TCRs have been shown to selectively bind to BCG-treated but not untreated DCs [43]. Whether these are mycobacteriaderived or endogenous phosphoantigens remains unclear. As shown by Kistowska et al. [44], mycobacterial infections disrupt isoprenoid biosynthesis in APCs, thus causing accumulation of endogenous phosphoantigens. Although mycobacteria-derived and/or endogenous phosphoantigens presented on infected DCs may activate $\gamma \delta$ T-cells, their role in $\gamma \delta$ T-cell activation by heat-killed preparations of mycobacteria is unclear.

We sought to determine the mechanisms by which heat-killed preparations of mycobacteria induce antitumour immune responses in $\gamma \delta$ T-cells. Our data suggest that $\mathrm{V} \delta 2^{+} \gamma \delta \mathrm{T}$-cells are indirectly activated by these mycobacterial preparations via IL-12, IL- $1 \beta$ and TNF- $\alpha$ produced by $\mathrm{mDC} 1 \mathrm{~s}$. Parenthetically, it is interesting to note that depleting monocytes from our system resulted in an increase in $\gamma \delta$ T-cell activation, which suggests that under certain conditions the bacterial preparations could trigger monocytes to release cytokines that counteract the effects of IL-12, IL- $1 \beta$ and TNF- $\alpha$. The newly proposed mechanism of activation is contrary to previous reports showing that DCs infected with heat-killed BCG fail to stimulate $\gamma \delta$ T-cells [23]. However, in this study cytokine-dependent activation of $\mathrm{V} \delta 2^{+} \gamma \delta$ T-cells by mDC1s was observed in co-cultures consisting of $\gamma \delta$ T-cells and $\mathrm{CD} 4^{+}$cells. Therefore, cytokine production by $\mathrm{mDC} 1 \mathrm{~s}$ in response to mycobacteria may be dependent on other cells within the $\mathrm{CD} 4^{+}$population. Accordingly, we found that $\gamma \delta$ T-cells failed to respond to the heat-killed mycobacteria when co-cultured with purified monocytes or $\mathrm{mDC} 1 \mathrm{~s}$ (data not shown). This is in keeping with previous reports that pathogen-induced IL-12 production by DCs is dependent on costimulatory signals such as CD40 ligation, which may be supplied by the T-cell component of the $\mathrm{CD}^{+}$cell population [45]. The mechanisms underlying $\mathrm{mDC} 1$ cytokine production did not fall within the scope of this study and investigations are currently underway.

The observations that heat-killed mycobacteria fail to activate $\gamma \delta$ T-cells co-cultured with purified DCs (i.e. in the absence of other $\mathrm{CD} 4^{+}$cells) suggests that phosphoan- tigen recognition is not involved in the $\gamma \delta$ T-cell responses observed here (Figs. 1, 2). It is possible that heat-killing stunts the efficacy of phosphoantigens or perturbs their uptake and processing by $\mathrm{mDC} 1 \mathrm{~s}$. Seeing as cancer immunotherapies use either heat-killed or low-viability preparations of mycobacteria, the newly identified mechanism of indirect cytokine priming compared with direct phosphoantigen recognition is more clinically relevant. Furthermore, in terms of generating an anti-tumour $\gamma \delta$ T-cell response, the indirect cytokine-mediated priming described here may elicit more favourable responses compared with direct phosphoantigen-mediated activation. Phosphoantigens are target molecules for $\gamma \delta$ T-cell cytotoxicity. Therefore, using these target molecules to prime $\gamma \delta$ T-cells for immunotherapeutic purposes will cause degranulation, which may exhaust $\gamma \delta$ T-cell cytotoxic responses before they encounter tumour. This has bearing on the use of heat-killed instead of live mycobacteria for cancer immunotherapy; indeed, reports have shown that $\gamma \delta$ T-cells kill APCs harbouring viable bacterial infections [46]. This also has bearing on immunotherapies that activate $\gamma \delta$ T-cells via phosphoantigens, either in situ (i.e. via systemic application of ABPs) or ex vivo (i.e. via adoptive transfer of phosphoantigen-expanded $\gamma \delta$ T-cells). In contrast, heat-killed mycobacteria, which indirectly prime $\gamma \delta$ T-cells via cytokines from $\mathrm{mDC} 1 \mathrm{~s}$, may not exhaust $\gamma \delta$ T-cell responses before they encounter tumour. This effect could be exploited to improve immunotherapies so as to avoid exhaustion of $\gamma \delta$ T-cells prior to tumour infiltration; for example, by combining systemic administration of mycobacteria with intratumoural administration of ABPs.

In summary, we demonstrate the potential for heatkilled preparations of BCG, $M$. vaccae and M. obuense to prime an anti-tumour effect in $\gamma \delta$ T-cells. Priming is mediated by cytokines from $\mathrm{mDC} 1 \mathrm{~s}$ and results in production of $\mathrm{T}_{\mathrm{H}} 1$ cytokines and increased cytotoxicity towards tumour cells. Our data provide a potential explanation for the anti-tumour effects of these mycobacterial preparations in vivo. Furthermore, our data suggest that these immunotherapies can be further developed using combination therapy, for example, combining systemic BCG, $M$. vaccae and M. obuense with localised ABPs or chemotherapies that augment $\gamma \delta$ T-cell susceptibility of target cells. More studies are required to elucidate the full range of effects elicited by these mycobacterial preparations, which are currently underway.

Acknowledgments We thank the Cancer Vaccine Institute for funding this project and Professor John Stanford for supplying the heatkilled preparations of $M$. vaccae and $M$. obuense.

Conflict of interest The authors declare no financial or commercial conflict of interest. 
Open Access This article is distributed under the terms of the Creative Commons Attribution Noncommercial License which permits any noncommercial use, distribution, and reproduction in any medium, provided the original author(s) and source are credited.

\section{References}

1. Herr HW, Morales A (2008) History of bacillus Calmette-Guerin and bladder cancer: an immunotherapy success story. J Urol 179(1):53-56

2. Maraveyas A, Baban B, Kennard D, Rook GA, Westby M, Grange JM, Lydyard P, Stanford JL, Jones M, Selby P, Dalgleish AG (1999) Possible improved survival of patients with stage IV AJCC melanoma receiving SRL 172 immunotherapy: correlation with induction of increased levels of intracellular interleukin-2 in peripheral blood lymphocytes. Ann Oncol 10(7):817-824

3. O'Brien ME, Saini A, Smith IE, Webb A, Gregory K, Mendes R, Ryan C, Priest K, Bromelow KV, Palmer RD, Tuckwell N, Kennard DA, Souberbielle BE (2000) A randomized phase II study of SRL172 (Mycobacterium vaccae) combined with chemotherapy in patients with advanced inoperable non-small-cell lung cancer and mesothelioma. Br J Cancer 83(7):853-857

4. Eaton JD, Perry MJ, Nicholson S, Guckian M, Russell N, Whelan M, Kirby RS (2002) Allogeneic whole-cell vaccine: a phase I/II study in men with hormone-refractory prostate cancer. BJU Int 89(1):19-26

5. Patel PM, Sim S, O'Donnell DO, Protheroe A, Beirne D, Stanley A, Tourani JM, Khayat D, Hancock B, Vasey P, Dalgleish A, Johnston C, Banks RE, Selby PJ (2008) An evaluation of a preparation of Mycobacterium vaccae (SRL172) as an immunotherapeutic agent in renal cancer. Eur J Cancer 44(2):216-223

6. O'Brien ME, Anderson H, Kaukel E, O'Byrne K, Pawlicki M, Von Pawel J, Reck M, SR-ON-12 Study Group (2004) SRL172 (killed Mycobacterium vaccae) in addition to standard chemotherapy improves quality of life without affecting survival, in patients with advanced non-small-cell lung cancer: phase III results. Ann Oncol 15(6):906-914

7. Stanford JL, Stanford CA, O'Brien ME, Grange JM (2008) Successful immunotherapy with Mycobacterium vaccae in the treatment of adenocarcinoma of the lung. Eur J Cancer 44(2):224-227

8. Stebbing J, Dalgleish A, Gifford-Moore A, Martin A, Gleeson C, Wilson G, Brunet LR, Grange J, Mudan S (2011) An intra-patient placebo-controlled phase I trial to evaluate the safety and tolerability of intradermal IMM-101 in melanoma. Ann Oncol. doi:10.1093/annonc/mdr363

9. Liu Z, Eltoum IE, Guo B, Beck BH, Cloud GA, Lopez RD (2008) Protective immunosurveillance and therapeutic antitumor activity of gammadelta $\mathrm{T}$ cells demonstrated in a mouse model of prostate cancer. J Immunol 180(9):6044-6053

10. Gao Y, Yang W, Pan M, Scully E, Girardi M, Augenlicht LH, Craft J, Yin Z (2003) Gamma delta T cells provide an early source of interferon gamma in tumor immunity. J Exp Med 198(3):433442

11. Girardi M, Oppenheim DE, Steele CR, Lewis JM, Glusac E, Filler R, Hobby P, Sutton B, Tigelaar RE, Hayday AC (2001) Regulation of cutaneous malignancy by gammadelta $\mathrm{T}$ cells. Science 294(5542):605-609

12. Morita CT, Jin C, Sarikonda G, Wang H (2007) Nonpeptide antigens, presentation mechanisms, and immunological memory of human Vgamma2Vdelta2 $\mathrm{T}$ cells: discriminating friend from foe through the recognition of prenyl pyrophosphate antigens. Immunol Rev 215:59-76

13. Wang MH, Chen YQ, Gercken J, Ernst M, Böhle A, Flad HD, Ulmer AJ (1993) Specific activation of human peripheral blood gamma/delta + lymphocytes by sonicated antigens of Mycobacterium tuberculosis: role in vitro in killing human bladder carcinoma cell lines. Scand J Immunol 38(3):239-246

14. Wrobel P, Shojaei H, Schittek B, Gieseler F, Wollenberg B, Kalthoff H, Kabelitz D, Wesch D (2007) Lysis of a broad range of epithelial tumour cells by human gamma delta $\mathrm{T}$ cells: involvement of NKG2D ligands and T-cell receptor- versus NKG2Ddependent recognition. Scand J Immunol 66(2-3):320-328

15. Choudhary A, Davodeau F, Moreau A, Peyrat MA, Bonneville M, Jotereau F (1995) Selective lysis of autologous tumor cells by recurrent gamma delta tumor-infiltrating lymphocytes from renal carcinoma. J Immunol 154(8):3932-3940

16. Bouet-Toussaint F, Cabillic F, Toutirais O, Le Gallo M, Thomas de la Pintière C, Daniel P, Genetet N, Meunier B, Dupont-Bierre E, Boudjema K, Catros V (2008) Vgamma9 Vdelta2 T cell-mediated recognition of human solid tumors. Potential for immunotherapy of hepatocellular and colorectal carcinomas. Cancer Immunol Immunother 57(4):531-539

17. Lucey DR, Clerici M, Shearer GM (1996) Type 1 and type 2 cytokine dysregulation in human infectious, neoplastic, and inflammatory diseases. Clin Microbiol Rev 9(4):532-562

18. Shen Y, Zhou D, Qiu L, Lai X, Simon M, Shen L, Kou Z, Wang Q, Jiang L, Estep J, Hunt R, Clagett M, Sehgal PK, Li Y, Zeng X, Morita CT, Brenner MB, Letvin NL, Chen ZW (2002) Adaptive immune response of Vgamma2Vdelta2 + T cells during mycobacterial infections. Science 295(5563):2255-2258

19. Garrido F, Algarra I, García-Lora AM (2010) The escape of cancer from T lymphocytes: immunoselection of MHC class I loss variants harboring structural-irreversible "hard" lesions. Cancer Immunol Immunother 59(10):1601-1606

20. Rincon-Orozco B, Kunzmann V, Wrobel P, Kabelitz D, Steinle A, Herrmann T (2005) Activation of V gamma 9V delta $2 \mathrm{~T}$ cells by NKG2D. J Immunol 175(4):2144-2151

21. Wesch D, Marx S, Kabelitz D (1997) Comparative analysis of alpha beta and gamma delta $\mathrm{T}$ cell activation by Mycobacterium tuberculosis and isopentenyl pyrophosphate. Eur J Immunol 27(4):952-956

22. Balaji KN, Boom WH (1998) Processing of Mycobacterium tuberculosis bacilli by human monocytes for CD4+ alphabeta and gammadelta $T$ cells: role of particulate antigen. Infect Immun 66(1):98-106

23. Martino A, Casetti R, Sacchi A, Poccia F (2007) Central memory Vgamma9Vdelta2 $\mathrm{T}$ lymphocytes primed and expanded by bacillus Calmette-Guérin-infected dendritic cells kill mycobacterial-infected monocytes. J Immunol 179(5):3057-3064

24. Skeen MJ, Ziegler HK (1995) Activation of gamma delta T cells for production of IFN-gamma is mediated by bacteria via macrophage-derived cytokines IL-1 and IL-12. J Immunol 154(11):5832-5841

25. Ueta C, Kawasumi H, Fujiwara H, Miyagawa T, Kida H, Ohmoto Y, Kishimoto S, Tsuyuguchi I (1996) Interleukin-12 activates human gamma delta T cells: synergistic effect of tumor necrosis factor-alpha. Eur J Immunol 26(12):3066-3073

26. Dieli F, Caccamo N, Meraviglia S, Ivanyi J, Sireci G, Bonanno CT, Ferlazzo V, La Mendola C, Salerno A (2004) Reciprocal stimulation of gammadelta $\mathrm{T}$ cells and dendritic cells during the anti-mycobacterial immune response. Eur J Immunol 34(11):3227-3235

27. Ziegler-Heitbrock L, Ancuta P, Crowe S, Dalod M, Grau V, Hart DN, Leenen PJ, Liu YJ, MacPherson G, Randolph GJ, Scherberich J, Schmitz J, Shortman K, Sozzani S, Strobl H, Zembala M, Austyn JM, Lutz MB (2010) Nomenclature of monocytes and dendritic cells in blood. Blood 116(16):e74-e80

28. Wroblewski JM, Bixby DL, Borowski C, Yannelli JR (2001) Characterization of human non-small cell lung cancer (NSCLC) cell lines for expression of MHC, co-stimulatory molecules and tumor-associated antigens. Lung Cancer 33(2-3):181-194 
29. Hallermalm K, Seki K, Wei C, Castelli C, Rivoltini L, Kiessling R, Levitskaya J (2001) Tumor necrosis factor-alpha induces coordinated changes in major histocompatibility class I presentation pathway, resulting in increased stability of class I complexes at the cell surface. Blood 98(4):1108-1115

30. Dormond O, Lejeune FJ, Ruegg C (2002) Modulation of cdk2, cyclin D1, p16INK4a, p21WAF and p27Kip1 expression in endothelial cells by TNF/IFN gamma. Anticancer Res 22(6A):3159-3163

31. Egwuagu CE, Li W, Yu CR, Che Mei Lin M, Chan CC, Nakamura $\mathrm{T}$, Chepelinsky $\mathrm{AB}$ (2006) Interferon-gamma induces regression of epithelial cell carcinoma: critical roles of IRF-1 and ICSBP transcription factors. Oncogene 25(26):3670-3679

32. Bradley LM, Dalton DK, Croft M (1996) A direct role for IFNgamma in regulation of Th1 cell development. J Immunol 157(4):1350-1358

33. Prévost-Blondel A, Roth E, Rosenthal FM, Pircher H (2000) Crucial role of TNF-alpha in CD8 T cell-mediated elimination of 3LL-A9 Lewis lung carcinoma cells in vivo. J Immunol 164(7):3645-3651

34. Seo N, Hayakawa S, Takigawa M, Tokura Y (2001) Interleukin10 expressed at early tumour sites induces subsequent generation of CD4(+) T-regulatory cells and systemic collapse of antitumour immunity. Immunology 103(4):449-457

35. Todaro M, D'Asaro M, Caccamo N, Iovino F, Francipane MG, Meraviglia S, Orlando V, La Mendola C, Gulotta G, Salerno A, Dieli F, Stassi G (2009) Efficient killing of human colon cancer stem cells by gammadelta $\mathrm{T}$ lymphocytes. J Immunol 182(11):7287-7296

36. Alexander AA, Maniar A, Cummings JS, Hebbeler AM, Schulze DH, Gastman BR, Pauza CD, Strome SE, Chapoval AI (2008) Isopentenyl pyrophosphate-activated CD56 $+\gamma \delta$ T lymphocytes display potent antitumor activity toward human squamous cell carcinoma. Clin Cancer Res 14(13):4232-4240

37. Mattarollo SR, Kenna T, Nieda M, Nicol AJ (2007) Chemotherapy and zoledronate sensitize solid tumour cells to Vgamma9Vdelta2 $\mathrm{T}$ cell cytotoxicity. Cancer Immunol Immunother 56(8):12851297
38. Wilhelm M, Kunzmann V, Eckstein S, Reimer P, Weissinger F, Ruediger T, Tony HP (2003) Gammadelta T cells for immune therapy of patients with lymphoid malignancies. Blood 102(1):200-206

39. Dieli F, Vermijlen D, Fulfaro F, Caccamo N, Meraviglia S, Cicero G, Roberts A, Buccheri S, D'Asaro M, Gebbia N, Salerno A, Eberl M, Hayday AC (2007) Targeting human $\gamma \delta$ T cells with zoledronate and interleukin-2 for immunotherapy of hormone-refractory prostate cancer. Cancer Res 67(15):7450-7457

40. Santini D, Martini F, Fratto ME, Galluzzo S, Vincenzi B, Agrati C, Turchi F, Piacentini P, Rocci L, Manavalan JS, Tonini G, Poccia F (2009) In vivo effects of zoledronic acid on peripheral gammadelta $\mathrm{T}$ lymphocytes in early breast cancer patients. Cancer Immunol Immunother 58(1):31-38

41. Serefoglu EC, Tandogdu Z (2010) Efficacy and safety of zoledronic acid in the treatment of glucocorticoid-induced osteoporosis. Ther Clin Risk Manag 6:219-223

42. Miyagawa F, Tanaka Y, Yamashita S, Minato N (2001) Essential requirement of antigen presentation by monocyte lineage cells for the activation of primary human gamma delta $\mathrm{T}$ cells by aminobisphosphonate antigen. J Immunol 166(9):5508-5514

43. Wei H, Huang D, Lai X, Chen M, Zhong W, Wang R, Chen ZW (2008) Definition of APC presentation of phosphoantigen (E)-4hydroxy-3-methyl-but-2-enyl pyrophosphate to Vgamma2Vdelta 2 TCR. J Immunol 181(7):4798-4806

44. Kistowska M, Rossy E, Sansano S, Gober HJ, Landmann R, Mori L, De Libero G (2008) Dysregulation of the host mevalonate pathway during early bacterial infection activates human TCR gamma delta cells. Eur J Immunol 38(8):2200-2209

45. Schulz O, Edwards AD, Schito M, Aliberti J, Manickasingham S, Sher A, Reis e Sousa C (2000) CD40 triggering of heterodimeric IL-12 p70 production by dendritic cells in vivo requires a microbial priming signal. Immunity 13(4):453-462

46. Dieli F, Troye-Blomberg M, Ivanyi J, Fournié JJ, Bonneville M, Peyrat MA, Sireci G, Salerno A (2000) Vgamma9/Vdelta2 T lymphocytes reduce the viability of intracellular Mycobacterium tuberculosis. Eur J Immunol 30(5):1512-1519 